ZOOLOGIA 27 (2): 191-200, April, 2010

doi: $10.1590 /$ S1984-46702010000200006

\title{
Meso and microhabitat analysis and feeding habits of small nektonic characins (Teleostei: Characiformes) in Neotropical streams
}

\author{
Mônica Ceneviva-Bastos ${ }^{1,2}$; Lilian Casatti ${ }^{1}$ \& Denise Cerqueira Rossa-Feres ${ }^{1}$
}

\author{
${ }^{1}$ Departamento de Zoologia e Botânica, Universidade Estadual Paulista. Rua Cristóvão Colombo 2265, 15054-000 São José \\ do Rio Preto, São Paulo, Brazil. \\ 2 Corresponding author. E-mail: mcbastos@gmail.com
}

\begin{abstract}
The habitat use and feeding habits of a set of nektonic fish species often found in small low-gradient streams in Brazil were investigated. The core species in the present study was Knodus moenkhausii (Eigenmann \& Kennedy, 1903), the most abundant of five species in the nektonic guild. Records of the species in 22 streams indicate that $K$. moenkhausii is associated, on a mesohabitat scale, with runs, and on a microhabitat scale, with sandy bottoms, intermediate depth, and open sites without coverage or submerged vegetation. During snorkeling observations, two additional nektonic registered species showed spatial segregation from $K$. moenkhausii with respect to foraging microhabitats. Feeding habits of the observed nektonic species were significantly correlated with riparian vegetation. The six species studied appear to use different resources, as suggested by a non-metric ordination of diet, and sites with characteristic riparian vegetation. The studied species may be considered generalists with a tendency to insectivory, with $K$. moenkhausii feeding on the widest variety of resources. Such opportunism explains its ability to successfully occupy instream habitats with low complexity.
\end{abstract}

KEY WORDS. Characidae; habitat use; resources; Upper Paraná.

Several environmental factors, acting separately or jointly, can influence the occurrence and habitat use of stream fishes. Consequently, these factors must be considered when trying to understand the community structure, and the interactions between species and their habitat (see Rincón 1999). Furthermore, studies on habitat use should be conduced on different scales, and should identify the abiotic variables that most strongly influence species distribution and abundance. The correct determination of these abiotic variables is important for restoration and management of aquatic ecosystems (Bond \& LAKE 2003), making it possible to evaluate the impact of human activities such as siltation (Lовв \& ORтн 1991) and canopy removal, which have been responsible for great losses of stream fish habitat quality (CASATTI et al. 2006).

Because instream variations in physical attributes are likely to be directly linked to changes in food sources (RINCón 1999), habitats in different stages of degradation have different levels of transportation, transformation, and stock of energy, indicating changes in the community composition at all trophic levels (GoldsteIN \& SimON 1999). As anthropogenic alterations intensify in streams, the local trophic structure may change to the point that most species found in these habitats will be generalists or opportunists; these species are capable of consuming a great variety of food resources. Because they are tolerant to habitat loss and degradation on a wide scale, many can become dominant in their communities.

Knodus moenkhausii (Eigenmann \& Kennedy, 1903) was the third most abundant of the 64 species registered in 95 streams in the upper Rio Paraná system, Brazil, representing $11 \%$ of the total fish abundance. In these streams, Astyanax altiparanae Garutti \& Britski, 2000, Astyanax fasciatus (Cuvier, 1819), Bryconamericus stramineus Eigenmann, 1908, Hemigrammus marginatus Ellis, 1911, and Piabina argentea Reinhardt, 1867, often co-occur with K. moenkhausii, although with a lower relative abundance (CASSATI et al. 2009).

Since all of the former are water column nektonic species (CASATTI \& CASTRO 1998) and belong to the same guild (sensu PIANKA 2000), they are herein referred to as belonging to a so called "nektonic guild".

Considering the numerical importance of K. moenkhausii within the nektonic guild of the communities where it occurs, the present study was conducted with the following goals: (I) to investigate the influence of abiotic factors on the occurrence of $K$. moenkhausii at the mesohabitat scale; (II) to describe $K$. moenkhausii microhabitat use through underwater observations, along with other co-occurring nektonic species; and (III) to investigate the feeding habitats of $K$. moenkhausii and other co-occurring nektonic species evaluating possible diet associations with environmental descriptors. 


\section{MATERIAL AND METHODS}

The study site, situated in north-western São Paulo (Brazilian state), is characterized by a hot tropical climate (NIMER 1989) and is used primarily for livestock grazing. The rainy season is often registered from October to March, with maximum average temperature $\left(31^{\circ} \mathrm{C}\right)$ in January, followed by a dry season from April to September, with minimum average temperature $\left(13^{\circ} \mathrm{C}\right)$ registered in July (IPT 2000).

Samples were taken during the 2003-2004 dry seasons from tributary streams of the rivers São José dos Dourados, Turvo, and Grande (see Appendix 1). Standardized electrofishing (two passes of 25 minutes each) was conducted across all 95 collecting sites, in a $75 \mathrm{~m}$ stream section previously blocked by $5 \mathrm{~mm}$ mesh stop-nets located up and downstream. Specimens were fixed in $10 \%$ formalin, transferred to $70 \% \mathrm{EtOH}$, and deposited in the fish collection of the Departamento de Zoologia e Botânica, Universidade Estadual Paulista, São José do Rio Preto, São Paulo (DZSJRP).

The occurrence and mesohabitat use of K. moenkhausii and other nektonic species were evaluated in 22 (Appendix 1) of the 95 streams sampled. In this analysis, our goals were to determine whether the distribution and abundance of the set of nektonic species were associated with particular stream features, and whether their spatial distribution could be explained by habitat descriptors. In order to accomplish that, we performed a Canonical Correspondence Analysis (CCA) using the
CANOCO 4.5 software (Ter BraAk \& Smilauer 2002) based on matrices with habitat variables and species abundance. Neither data transformation, nor interaction terms were defined, and no rescaling was selected among the CANOCO options. Nevertheless, rare species were down weighted.

Amongst 16 environmental descriptors used in the exploratory analysis, seven (those showing highest correlations with species abundance) were selected and categorized in an environmental matrix (Tab. I). Because habitat volume was not equal between sites, the relative abundance of each species was calculated by its abundance per habitat volume. The habitat volume, consisting of the water volume contained in the sampled stream stretch, was calculated (depth $\mathrm{x}$ width $\mathrm{x}$ length) and a matrix of species abundance per volume of habitat was constructed to minimize any bias.

In order to determine which microhabitats are predominantly exploited by K. moenkhausii, snorkeling sessions were conducted in a segment of an additional stream, the Ribeirão do Arara $\left(20^{\circ} 09^{\prime} 28.3^{\prime \prime} \mathrm{S} 50^{\circ} 32^{\prime} 17.6^{\prime \prime} \mathrm{W}\right)$, a Rio Grande tributary located in the municipality of Dolcinópolis. Diving sessions were performed on three occasions $\left(11^{\text {th }}\right.$ September, $08^{\text {th }}$ October and $06^{\text {th }}$ November 2005), following a sampling protocol modified from AranHa et al. (1998), in which a $10 \mathrm{~m}$ stream stretch was delimited and eight observation points were equally distributed (Fig. 1). At each point, observations were conducted during 10 minutes (for a total of 240 minutes), and five habitat descriptors were recorded (Tab. I).

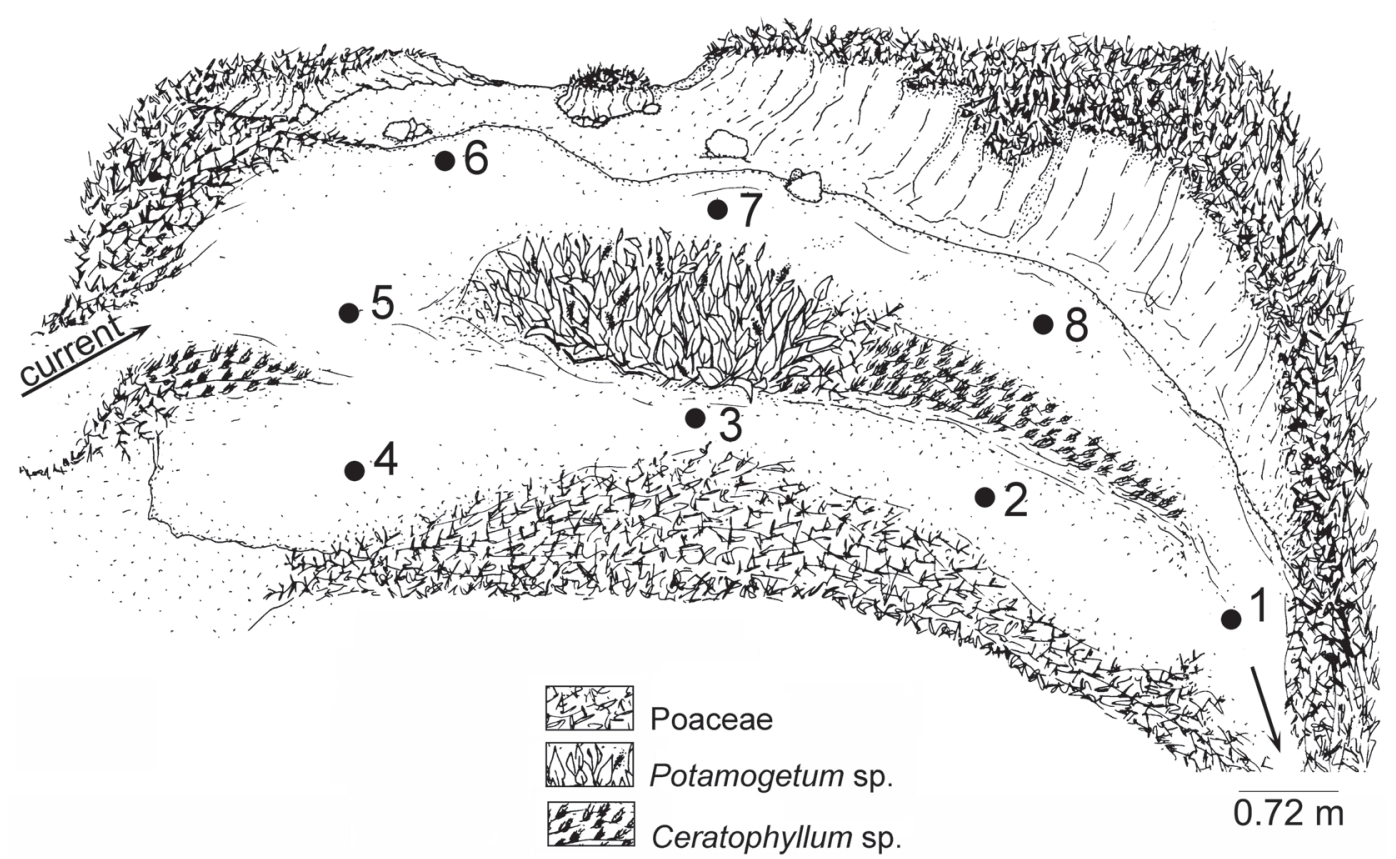

Figure 1. Outline drawing of the studied site in northwestern São Paulo State, showing points where underwater observations were conducted (1-8) and plants contacting water predominant types.

ZOOLOGIA 27 (2): 191-200, April, 2010 
Table I. Environmental descriptors used in mesohabitat, microhabitat, and diet analysis.

\begin{tabular}{|c|c|}
\hline Descriptors & Categories \\
\hline Instream wood debris abundance ${ }^{1}$ & 1 (absent), 2 (rare), 3 (abundant) or 4 (very abundant). \\
\hline \multirow[t]{3}{*}{ Type of predominant substrate $1,2,3$} & $\begin{array}{l}1 \text { (sand/silt, or silt, or clay, or rocks), } 2 \text { (sand/silt and clay, or sand/silt } \\
\text { and rocks), } 3 \text { (sand/silt and gravel/pebbles) or } 4 \text { (sand/silt, } \\
\text { gravel/pebbles and cobble/boulder). }\end{array}$ \\
\hline & 1 (clay), 2 (fine sand), 3 (medium sand) or 4 (detritus). ${ }^{2}$ \\
\hline & $\begin{array}{l}1 \text { (sand/silt, or silt, or clay, or rocks), } 2 \text { (sand/silt and clay, or sand/silt } \\
\text { and rock), } 3 \text { (sand/silt and pebbles) or } 4 \text { (sand/silt, pebbles and rocks). }{ }^{3}\end{array}$ \\
\hline Conductivity and turbidity ${ }^{1}$ & Not categorized; directly measured in the field with digital equipment. \\
\hline Proportion of pools, runs, and riffles ${ }^{1}$ & $\begin{array}{l}\text { Not categorized; evaluated as the percentage of each mesohabitat } \\
\text { extension along each stretch. }\end{array}$ \\
\hline Presence of marginal vegetation ${ }^{2}$ & 1 (absent), 2 (present on one bank) or 3 (present on both banks). \\
\hline Abundance of aquatic macrophytes (\% stretch coverage) ${ }^{2}$ & $\begin{array}{l}1 \text { (absent), } 2 \text { (covering up to } 25 \% \text { of the stretch), } 3 \text { (covering from } 25 \\
\text { to } 50 \% \text { of the stretch) or } 4 \text { (covering more than } 50 \% \text { of the stretch). }\end{array}$ \\
\hline $\begin{array}{l}\text { Current, given by the average of three measurements with a } \\
\text { mechanical flow meter } 2,3\end{array}$ & $\begin{array}{l}1 \text { (imperceptible), } 2 \text { (slow, from } 0 \text { to } 25 \mathrm{~cm} / \mathrm{s} \text { ), } 3 \text { (moderate, from } 25 \text { to } \\
50 \mathrm{~cm} / \mathrm{s} \text { ) or } 4 \text { (fast, higher than } 50 \mathrm{~cm} / \mathrm{s} \text { ). }\end{array}$ \\
\hline Mean depth, measured in each point ${ }^{2}$ & $\begin{array}{l}1(1-20 \mathrm{~cm}), 2(20-30 \mathrm{~cm}), 3(30-40 \mathrm{~cm}), 4(40-50 \mathrm{~cm}), 5(50-60 \mathrm{~cm}) \\
6(60-70 \mathrm{~cm}), 7(70-80 \mathrm{~cm}), 8(80-90 \mathrm{~cm}) \text { or } 9(90-103 \mathrm{~cm}) .\end{array}$ \\
\hline
\end{tabular}

Abundance of vegetation contacting water (bank coverage) ${ }^{3} 1$ (absent), 2 (covering up to $25 \%$ of the stretch), 3 (covering from 25 to $50 \%$ of the stretch) or 4 (covering more than $50 \%$ of the stretch).

Riparian vegetation ${ }^{3}$

1 (absent), 2 (shrubs) or 3 (trees).

Turbidity $^{3} \quad 1$ (low, from 0 to $100 \mu \mathrm{S} / \mathrm{cm}$ ) or 2 (high, $>100 \mu \mathrm{S} / \mathrm{cm}$ ).

${ }^{1}$ Descriptors and their categories used for mesohabitat analysis. ${ }^{2}$ Descriptors and their categories used for microhabitat analysis.

${ }^{3}$ Descriptors and their categories used to evaluate correlations with species diet.

Besides environmental characterization during observation sessions, all fish species present were recorded along with data on the abundance of each fish group or shoal, the vertical position of each specimen (bottom, middle, surface), the horizontal position of each specimen in relation to the banks (closer to left or right bank or in the middle), and feeding tactics.

To calculate the correlation of the microhabitat descriptors mentioned above and the abundance of K. moenkhausii a Mantel test was carried out, using Euclidean Distance coefficient of similarity for descriptors matrix and Morisita-Horn for the abundance matrix. This analysis was performed with the option of normalization and 5,000 permutations in NTSYSpc software (RoHLF 2000). From the resulting microhabitat similarity triangular matrix, a dendrogram was generated using Unweighted Pair Group Method with Arithmetic mean (UPGMA) cluster method. In this dendrogram, abundance categories for K. moenkhausii were subsequently plotted. Feeding analysis of K. moenkhausii and other nektonic species was performed on fishes sampled in 15 (Appendix 1) of the 95 streams. The 15 streams were chosen because they had an adequate number of specimens for gut content analysis. Gut contents of 10 adult specimens from each stream were examined under stereomicroscope and identified to the lowest recognizable taxon. Percent composition by number, frequency of occur- rence (Gelwick \& MatThews 1996) and dominance (HyNes 1950) were calculated for each item. The most important feeding items were determined using BenNemann's et al. (2006) method, an adaptation of Costello's (1990) method, in which item dominance is employed instead of item weight. Items plotted on the upper right of the diagram are more frequent and dominant and, hence, are assumed to be more important in the diet of the species; by contrast, when several items are located on the lower portion of the diagram, a tendency to trophic opportunism is suggested.

An exploratory ordination technique (NMDS - Non-Metric Multidimensional Scaling Analysis) was employed to evaluate similarities between fish diets using a matrix with food items grouped into the following categories: algae, aquatic insects, crustaceans, fish scales, macrophytes, fishes, nematodes, debris of vascular plants, arachnids, terrestrial insects, eggs, insects fragments, and detritus, the latter corresponding to any highly digested feeding item. Values of percent composition by number were $[\log (\mathrm{x}+1)]$ transformed and the Bray-Curtis similarity coefficient was calculated using PRIMER v6 software (CLARKE \& GORLEY 2006), after specifying 25 random re-starts. Stress values were 0.1 , indicating a good representation with no real prospect of a misleading interpretation (CLARKE \& WARWICK 2001). In the same software, correlations between habitat descriptors and $K$. 
moenkhausii and other species diet were evaluated by a Similarity Analysis (ANOSIM). A diet matrix containing the grouped items mentioned above was compared with another matrix containing environmental descriptors (Tab. I) which probably influence prey availabilities and capture success.

\section{RESULTS}

According to CCA results (Fig. 2, Tab. II), the runs proportion and turbidity were the most significant descriptors explaining species-environment relationships ( $\mathrm{p}=0.042$ and 0.020 respectively). The runs proportion was the unique environmental descriptor associated with K. moenkhausii. By contrast, branches and logs proportion, substrate type, and riffles proportion explained the abundances of $A$. altiparanae and $B$. stramineus. Hemigrammus marginatus is clearly associated with proportion of pools in the system, being the only species associated with Axis 2 (Fig. 2).

Based on data obtained during snorkeling sessions, specimens of K. moenkhausii were particularly associated with microhabitats $45 \mathrm{~cm}$ deep on average; without submerged vegetation; without coverage; and with sandy bottom covered by a fine detritus layer (Tab. III, Fig. 3). Like K. moenkhausii, A. altiparanae and $A$. fasciatus individuals were also registered in sandy bottoms without marginal vegetation or coverage, though they were less abundant under these conditions.

Specimens of K. moenkhausii were registered in 16 of the 24 observation sessions, and co-occurred with A. altiparanae and/or $A$. fasciatus in eight of them. On 12 occasions, interactions among individuals were observed (only at the points 4 , 5, 6 and 7; Fig. 1), either among K. moenkhausii individuals $(\mathrm{n}=9)$ or between K. moenkhausii and A. altiparanae or $A$. fasciatus individuals $(\mathrm{n}=3)$; of these, 10 interactions involved some kind of dispute or confrontation.

Adults of K. moenkhausii were only occasionally found in areas near the margin; whenever an adult K. moenkhausii moved to a marginal area previously occupied by individuals of $A$. altiparanae, the latter would immediately relocate to the middle of the channel, and then rapidly return to the margins, in the

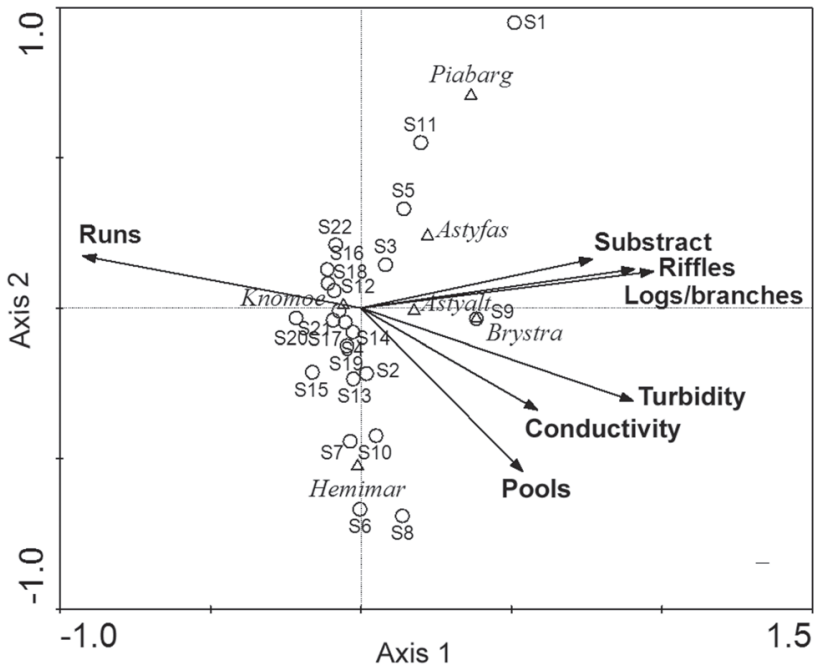

Figure 2. Ordination diagram resulting from canonical correspondence analysis, showing 22 sites (open circles), six species (dark triangles) and seven environmental descriptors (arrows). Axis 1 and 2 are significant when tested together $(p=0.008)$ according Monte Carlo test (499 permutations under reduced model), indicating that relationship between species abundance and environmental variables is stronger than expected by chance. (Astyalt) $A$. altiparanae, (Astyfas) A. fasciatus, (Brystra) B. stramineus, (Hemimar) H. marginatus, (Knomoe) K. moenkhausii, (Piabarg) P. argentea.

Table III. Correlation coefficient ( $r$ ) obtained by the Mantel test for microhabitat descriptors and K. moenkhausii abundance. * Probability $<0.05$.

\begin{tabular}{lc}
\hline \multicolumn{1}{c}{ Descriptors } & $\mathrm{r}$ \\
\hline Coverage * & 0.56 \\
Depth * & 0.40 \\
Substrate * & 0.62 \\
Submerged vegetation * & 0.54 \\
Current & 0.20 \\
\hline
\end{tabular}

Table II. Canonical correspondence analysis (CCA) summary showing the correlation between environmental descriptors and the abundance of nektonic species. All four reported eigenvalues are canonical and correspond to axes that are constrained by environmental variables.

\begin{tabular}{|c|c|c|c|c|c|}
\hline Axis & 1 & 2 & 3 & 4 & Total inertia ${ }^{2}$ \\
\hline Eigenvalues $^{1}$ & 0.386 & 0.174 & 0.056 & 0.007 & 1.215 \\
\hline Species-environment correlations & 0.918 & 0.652 & 0.457 & 0.309 & \\
\hline \multicolumn{6}{|l|}{ Cumulative percentage variance: } \\
\hline of species data & 31.800 & 46.100 & 50.700 & 51.300 & \\
\hline of species-environment relation & 62.000 & 89.800 & 98.800 & 99.000 & \\
\hline Sum of all canonical eigenvalues & & & & & 0.623 \\
\hline
\end{tabular}

\footnotetext{
${ }^{1}$ Eigenvalues measure the importance of each axis 2 Total inertia indicates the total variance.
} 


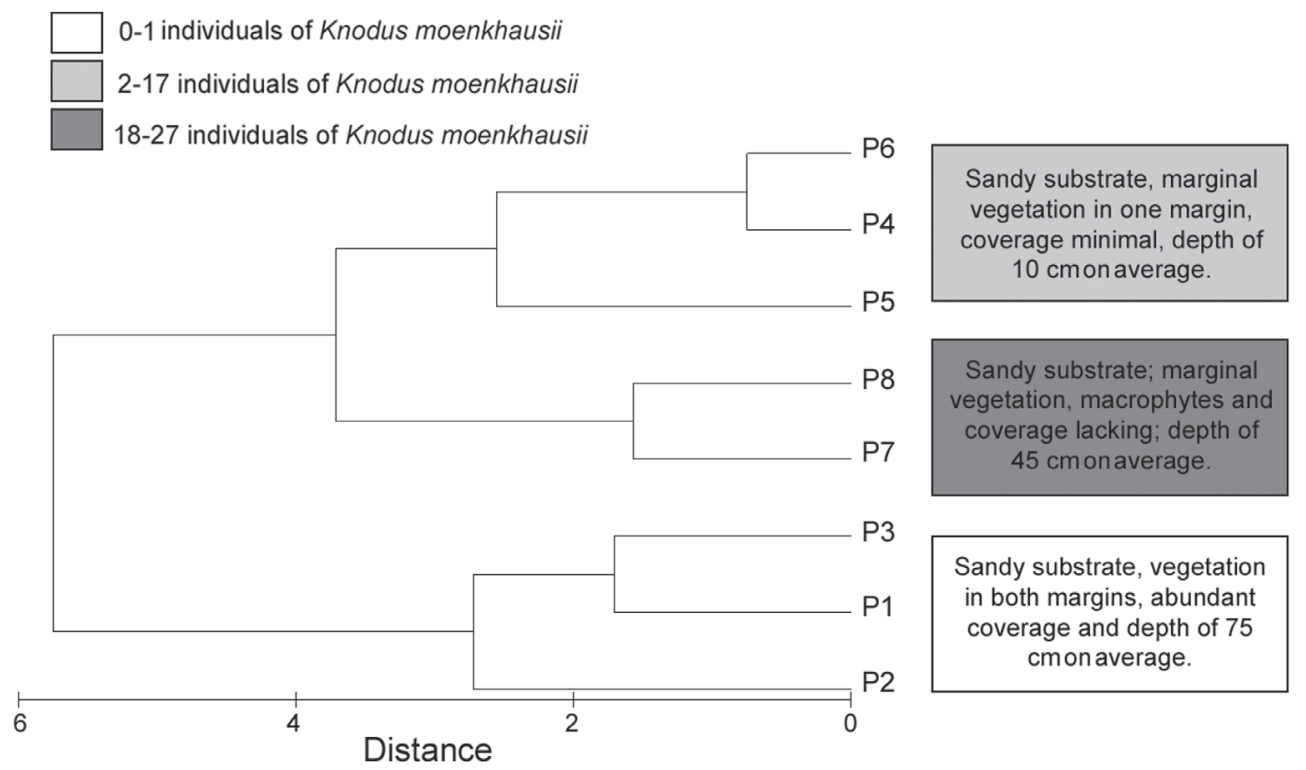

Figure 3. Dendrogram showing the three clusters obtained by the Euclidean Distance, considering four environmental descriptors (coverage, depth, substrate, and submerged vegetation) in a microhabitat scale analysis of $K$. moenkhausii occurrence based on eight points of observation $(P)$. Species abundances were posterior plotted in the figure.

same time that $K$. moenkhausii individuals returned to the middle of the channel. A similar kind of synchronized dislodgments also occurred between K. moenkhausii and A. fasciatus, between the middle of the water column and the stream bottom.

The three observed species showed continuous foraging behavior, capturing items drifted by current (i.e. drift feeding, see Grant \& NoAKES 1987), close to the bottom, on the water surface (i.e. surface picking, see SAZIMA 1986) or close to the margins. Spatial segregation during feeding activities was recorded with K. moenkhausii exploring mainly the middle of the water column (61\% of the registers), A. altiparanae foraging mostly closer to the margins (78\%) and $A$. fasciatus foraging closer to the bottom (46\%) (Fig. 4).

Percent composition by number revealed predominance of allochthonous items ( $46 \%$ of the total items for all species), dominated by terrestrial insects (34\%), with respect to autochthonous items (42\%), dominated by aquatic insects (29\%). Undetermined items, represented by eggs, detritus and unidentified debris, accounted for $12 \%$. The most important items were those with the highest frequencies and dominances (Fig. 5). Riparian vegetation was the exclusive descriptor that showed significant correlation with fish species diet (Table IV). Based on this result, the three conditions that represent the descriptor physiognomic states (absent, shrubs, or trees) were further plotted into an NMDS ordination diagram (Figs 6-7). Either for the set of nektonic species evaluated together (Fig. 6) or for $K$. moenkhausii (Fig. 7) alone, the ordination indicated that diet differed according to conditions of the riparian vegetation.

Table IV. ANOSIM summaries for environmental descriptors and species diet. $\mathrm{R}$ is a samples separation comparative measure, which varies from -1 to 1 (values close to zero indicate null hypothesis acceptance), $\mathrm{p}$ is the percentage of error Type I risk occurrence. * Significative values.

\begin{tabular}{|c|c|c|c|c|}
\hline \multirow{2}{*}{ Descriptors } & \multicolumn{2}{|c|}{ K. moenkhausii } & \multicolumn{2}{|c|}{ Other Characidae } \\
\hline & $\mathrm{R}$ & $p(\%)$ & $\mathrm{R}$ & $p(\%)$ \\
\hline Type of substrate & 0.09 & 25.9 & 0.18 & 8.50 \\
\hline Marginal vegetation contacting water & 0.05 & 34.0 & 0.13 & 13.4 \\
\hline Riparian vegetation & $0.30^{*}$ & 2.90 & $0.42^{*}$ & 0.50 \\
\hline Turbidity & -0.04 & 61.8 & -0.04 & 57.0 \\
\hline Current & 0.006 & 45.8 & 0.28 & 5.60 \\
\hline
\end{tabular}




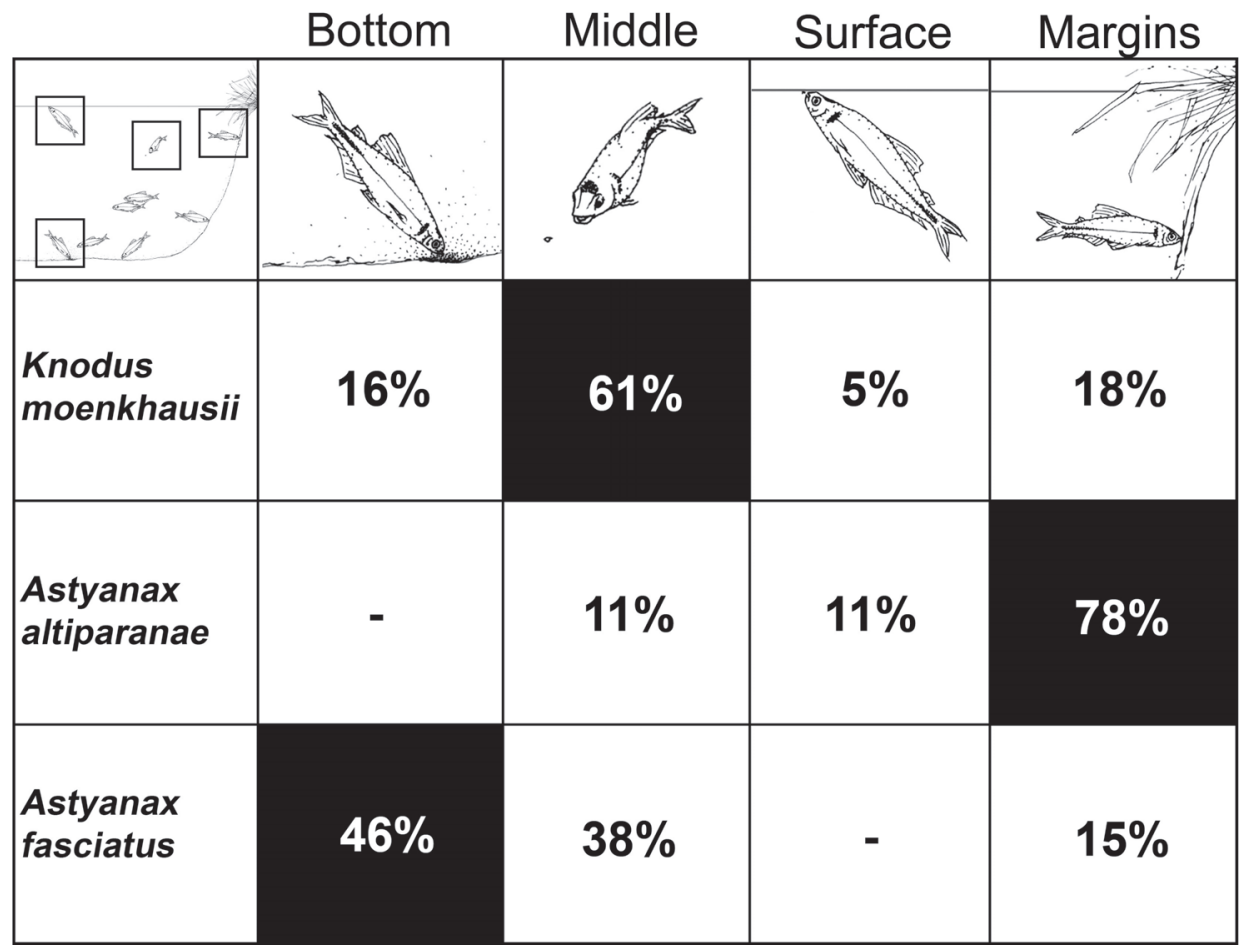

Figure 4. Foraging microhabitats in the water column and habitat use percentages, suggesting spatial segregation among three nektonic species.
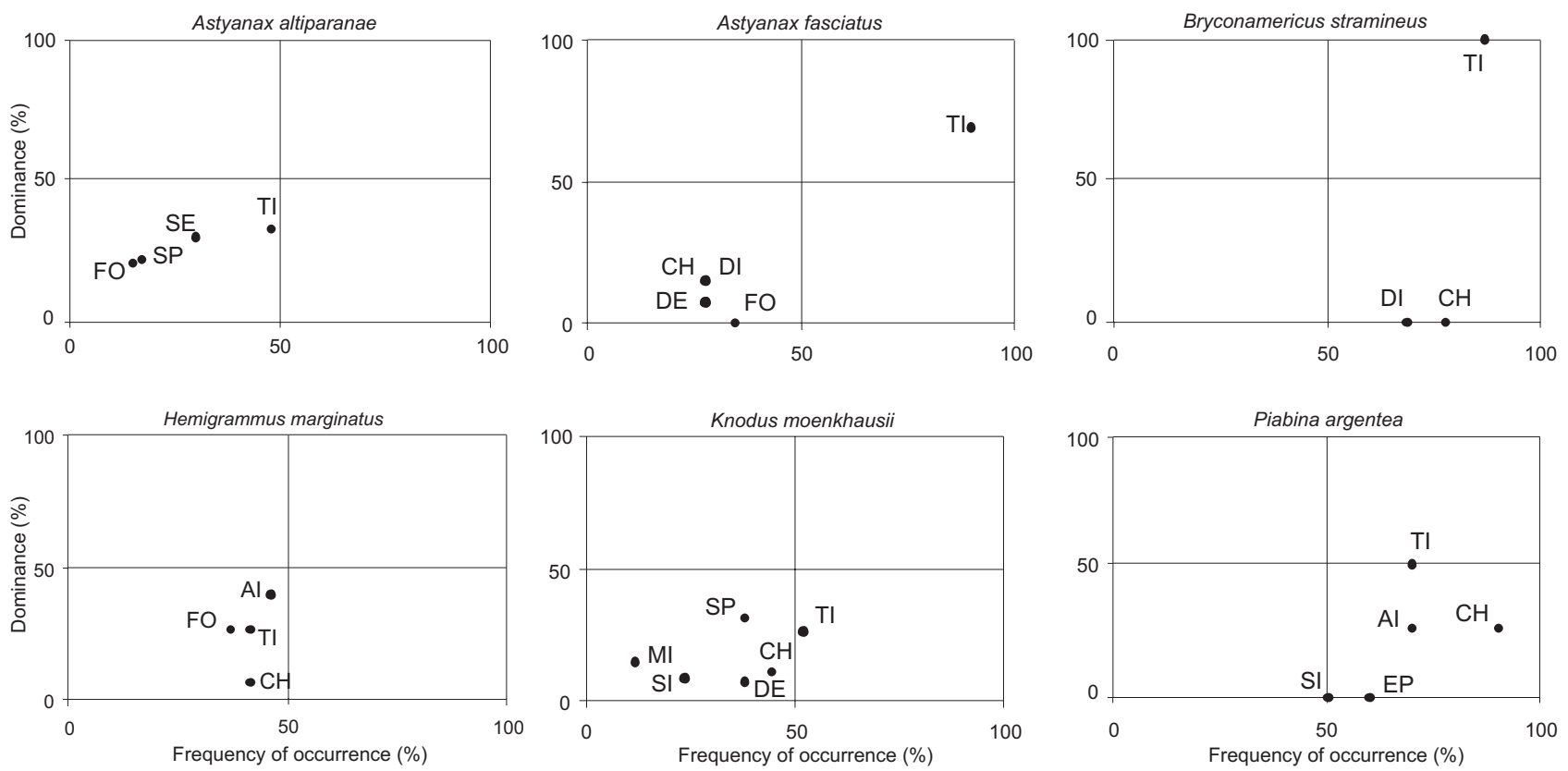

Figure 5. Frequency of occurrence (axis $\mathrm{x}$ ) and dominance (axis $\mathrm{y}$ ) of feeding items registered in gut contents of six nektonic species studied. (AI) Aquatic insects debris, (CH) Chironomidae larvae, (DE) detritus, (DI) Diptera aquatic larvae, (EP) Ephemeroptera nymphs, (FO) Formicidae in adult stages, (MI) Microspora sp., (SE) seeds of terrestrial plants, (SI) Simuliidae aquatic larvae, (SP) Spyrogira sp., (TI) terrestrial insects debris. 


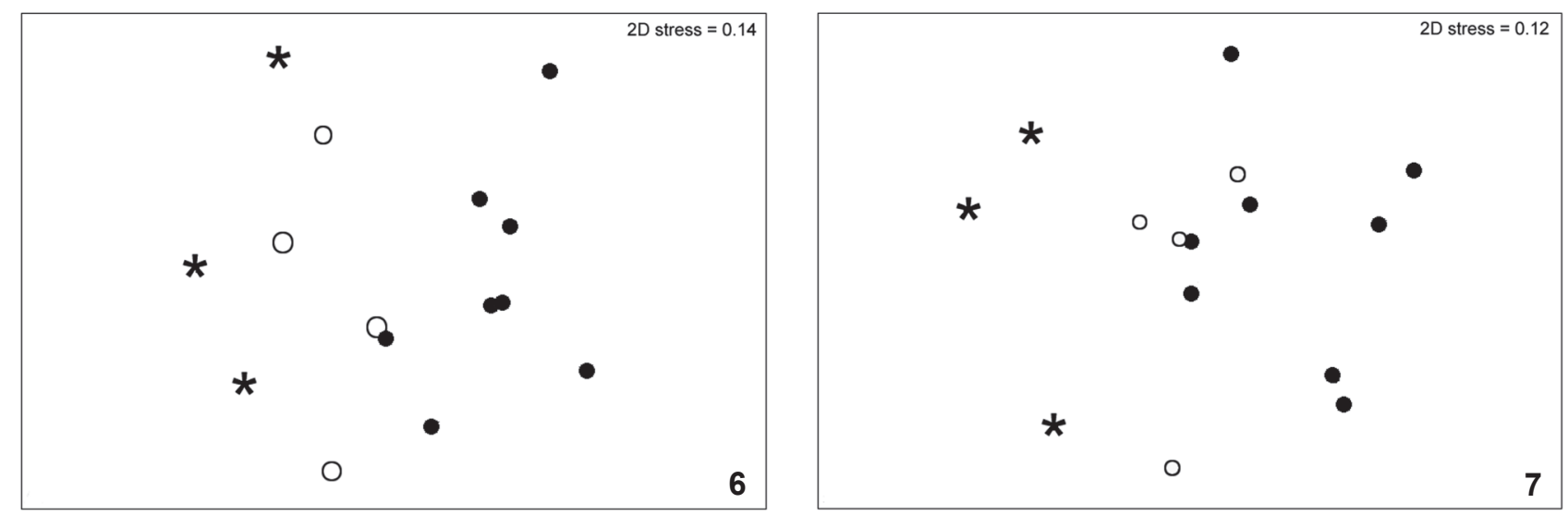

Figures 6-7. Ordination diagram representing two first axis of a Non-Metric Multidimensional Scaling Analysis of the six nektonic species and $K$. moenkhausii diet (6), and on the last species separately (7). Symbols represent sites according to riparian vegetation: absent (open circles), shrubs (star), and trees (dark circles).

\section{DISCUSSION}

On a mesohabitat scale, K. moenkhausii is particularly associated with runs, which are streams or river reaches with slow current, slightly deeper than riffles, with a smaller gradient and with non-turbulent waters (RINCón 1999). Most runs investigated in this study have sandy bottoms without branches or logs, or macrophytes, representing habitats with very low complexity, which offer limited microhabitat diversity. Several studies have pointed out that a higher diversity of microhabitats may support a more diversified fish fauna (GREGORY 1992, UIEDA \& Barreto 1999, BüHrnheim \& Cox Fernandes 2003, Braga 2004), mainly by offering more shelter possibilities and foraging sites (Delariva et al. 1994, Casatti et al. 2003). By contrast, few species can benefit from homogeneous habitats, contributing to higher species dominance in these communities (SILVA 1992). In fact, K. moenkhausii was one of the most dominant species in streams with low complexity, whereas in more heterogeneous streams, the relative abundance of other nektonic species increased, as observed for A. altiparanae and B. stramineus. These results suggest that $K$. moenkhausii has great ability to occupy disturbed sites, a fact that may partially explain its noticeable abundance in the streams of the study region.

The contribution of autochthonous and allochthonous items in the diet of the six species studied was similar, with autochthonous items being slightly more represented. According to LowEMcConNell (1987), allochthonous input is very important in the diet of stream fishes, a hypothesis that has been corroborated by several authors (SABino \& Castro 1990, Sabino \& Zuanon 1998, Claro JR et al. 2004, Melo et al. 2004); by contrast, autochthonous items have been found to be more relevant by some studies (COSTA 1987, Uieda et al. 1997, CASATTI 2002). Even in very shaded streams, autoch thonous microalgae productivity can be large enough to support all organisms in upper trophic levels (BRrTo et al. 2006).
The terms "generalist" and "opportunistic" have been widely used in stream fish studies particularly to characterize members of the Characidae (Aвelha et al. 2001, Ferreira et al. 2002, Rezende \& Mazzoni 2003, Bennemann et al. 2005, CenevivaBASTOS \& CASATTI 2007). These terms are used to classify species that feed on several taxa, have a wide trophic niche, and therefore belong to more than one trophic group (GOLDSTEIN \& SIMON 1999). These terms indicate the trophic plasticity, or feeding versatility, displayed by generalist and opportunist species, which can exploit certain alternative resources in the absence of their preferred items (GoldsTeIn \& SimON 1999, and see examples in Arcifa \& Meschiatti 1993, Esteves \& Galetti Jr 1995, Esteves 1996). Trophic plasticity is likely to be an important attribute of $K$. moenkhausii, since feeding habits can change according to resource availability (CENEviva-Bastos \& CASATTI 2007). Within this context, this species is likely to be little affected by habitat degradation.

Based on the discussion above, all species studied here can be considered generalists that consume a great amount of insects, an abundant resource in streams (ANGERMEIER 1985, KikUCHI \& Uieda 1998, Bueno et al. 2003, Costa et al. 2006). However, despite the fact that these species feed on similar items, they vary in their feeding tactics and foraging microhabitats. For example, B. stramineus frequently captures insects on the water surface (CASATTI \& CASTRO 1998), which explains the predominance of terrestrial insects in the diet of this species. Individuals of $H$. marginatus are also insectivores, but fed mainly on aquatic insects, which may be explained by their position in the middle of the water column (CASATTI et al. 2003), enhancing their opportunities to capture drifted autochthonous items.

Differences in feeding habits among sites were influenced by the presence of riparian vegetation. It is known that processes that occur in riparian zones influence the aquatic biota (Gregory 1992, Pusey \& Arthington 2003) and lead to changes 
in the diet of different fish species (see WaItE \& CARPENTER 2000, FERREIRA et al. 2002), reinforcing its importance as a buffer zone (Bojsen \& Barriga 2002, Sweeney et al. 2004, Poulet et al. 2005). It is important to mention that the presence of arboreal riparian vegetation, even in poor state of conservation, provided distinct feeding resources to the fish fauna, reinforcing the findings of a previous study carried out by the authors of this paper (Ceneviva-Bastos \& CasatTi 2007).

Spatial segregation of feeding sites was noticeable among three of the species studied. According to previous studies (UiEdA et al. 1997, Aranha et al. 1998, CASATti et al. 2003), differences in spatial distribution and foraging microhabitats suggest partitioning of feeding resources, minimizing the likelihood of competition among species. Competition occurs when a set of species, under natural conditions, has identical niches and resources are in short supply (WIENS 1977, PIANKA 2000). In order to identify an instance of competition, one or more of the species involved must show decreased fitness. Therefore, a dispute that one species wins and another species loses, depending on each species differential competitive abilities and their ability to deal with natural enemies (e.g. MorRis et al. 2004), is implied.

According to niche and competition theories, the synchronized dislodgement among K. moenkhausii and Astyanax spp., observed here, could be interpreted as a resource partitioning mechanism that prevents competition (SCHOENER 1974).

We believe, however, that rather than being a mechanism to avoid competition, the observed synchronized dislodgements correspond to individual adjustments to an environment that includes individuals of other species (Jorge Jim pers. comm.).

Thus, the spatial segregation observed between the species K. moenkhausii and Astyanax spp. might not be an arrangement to avoid competition, but a dynamic adjustment (J. Jim pers. com) among co-occurring species in relation to habitat (sensu MitchelL's 2005 habitat concept) conditions.

\section{ACKNOWLEDGEMENTS}

We thank our colleagues from the Laboratório de Ictiologia for their help during field work and the Zoologia e Botânica Department IBILCE-UNESP for letting us use their facilities; IBAMA for issuing a collecting license $(001 / 2003)$ on our behalf; Jorge Jim, Virgínia S. Uieda, and Sirlei T. Bennemann for their suggestions; Clarice Ceneviva and David R. Mercer for language review; Fernando B. Noll and Orlando Necchi Jr for helping us with the identification of feeding items. This study was made possible by funding from FAPESP (grants 01/13340-7, 04/122146) and CNPq (grants 141028/2007-6, 302838/2007-4).

\section{LITERATURE CITED}

Abelha, M.C.F.; A.A. Agostinho \& E. Goulart. 2001. Plasticidade trófica em peixes de água doce. Acta Scientiarum 23 (2): 425-434.
ANGERMEIER, P.L. 1985. Spatio-temporal patterns of foraging success for fishes in an Illinois stream. The American Naturalist 114 (2): 342-359.

Aranha, J.M.R.; D.F. Takeuti \& T.M. Yoshimura. 1998. Habitat use and food partitioning of the fishes in a costal stream of Atlantic Forest, Brazil. Revista de Biología Tropical 46 (4): 951-959.

Arcifa, M.S. \& A.J. Meschiatti. 1993. Distribution and feeding ecology of fishes in a brazilian reservoir: Lake Monte Alegre. Interciência 18 (66): 302-313.

Bennemann, S.T.; A.M. Gealh; M.L. Orsi \& L.M. Souza. 2005. Ocorrência e ecologia trófica de quatro espécies de Astyanax (Characidae) em diferentes rios da bacia do rio Tibagi, Paraná, Brasil. Iheringia, Série Zoologia, 95 (3): 247-254.

Bennemann, S.T.; L. Casatti \& D.C. Oliveira. 2006. Alimentação de peixes: proposta para análise de itens registrados em conteúdos gástricos. Biota Neotropica 6 (2): 1-8.

Bojsen, B.H. \& R. BARriga. 2002. Effects of deforestation on fish community structure in Ecuadorian Amazon streams. Freshwater Biology 47 (11): 2246-2260.

Bond, N.R. \& P.S. LAKE. 2003. Characterizing fish-habitat associations in streams as the first step in ecological restoration. Austral Ecology 28 (6): 611-621.

Braga, F.M.S. 2004. Hábitat, distribuição e aspectos adaptativos de peixes da microbacia do ribeirão Grande, Estado de São Paulo, Brasil. Acta Scientiarum 26 (1): 31-36.

Brito E.F.; T.P. Moulton; M.L. Souza \& S.E. Bunn. 2006. Stable isotope analysis indicates microalgae as the predominant food source of fauna in a coastal forest stream, south-east Brazil. Austral Ecology 31 (5): 623-633.

Bueno, A.A.P.; G. Bond-Buckup \& B.D.P. Ferreira. 2003. Estrutura da comunidade de invertebrados bentônicos em dois cursos d'água do Rio Grande do Sul, Brasil. Revista Brasileira de Zoologia 20 (1): 115-125.

Bührnheim, C.M. \& C. Cox Fernandes. 2003. Structure of fish assemblages in Amazonian Rain-Forest streams: effects of habitats and locality. Copeia 2003 (2): 255-262.

Casatti, L. 2002. Alimentação dos peixes em um riacho do Parque Estadual Morro do Diabo, bacia do Alto Paraná, sudeste do Brasil. Biota Neotropica 2 (2): 1-14.

Casatti, L. \& R.M.C. Castro. 1998. Fish community of the São Francisco river headwaters riffles, southeastern Brazil. Ichthyological Exploration of Freshwaters 9 (3): 229-242.

Casatti, L.; H.F. Mendes \& K.M. Ferreira. 2003. Aquatic macrophytes as feeding site for small fishes in the Rosana Reservoir, Paranapanema River, southeastern Brazil. Brazilian Journal of Biology 63 (2): 213-222.

Casatti, L.; F. Langeani; A.M. Silva \& R.M.C. Castro. 2006. Stream fish, water and habitat quality in a pasture dominated basin, southeastern Brazil. Brazilian Journal of Biology 66 (2): 681-696.

Casatti, L.; C.P. Ferreira; F.R. Carvalho. 2009. Grass-dominated stream sites exhibit low fish species diversity and dominance by guppies: an assessment of two tropical pasture river basins. Hydrobiologia 632 (1): 273-283. 
Ceneviva-Bastos, M. \& L. Casatti. 2007. Oportunismo alimentar de Knodus moenkhausii (Teleostei, Characidae): uma espécie abundante em riachos do sistema do Alto Paraná no Estado de São Paulo. Iheringia, Série Zoologia, 97 (1): 7-15.

Clarke, K.R. \& R. N. Gorley. 2006. Primer v6: user manual/ tutorial. Plymouth, Plymouth Marine Laboratory, 190p.

Clarke, K.R. \& R.M. WarWick. 2001. Change in marine communities: an approach to statistical analysis and interpretation. Plymouth, Plymouth Marine Laboratory, 172p.

Claro-Jr, L.; E. Ferreira; J. Zuanon \& C. Araújo-Lima. 2004. O efeito da floresta alagada na alimentação de três espécies de peixes onívoros em lagos de várzea da Amazônia Central, Brasil. Acta Amazonica 34 (1): 133-137.

Costa, C.; S. IdE \& C.E. SimonKA. 2006. Insetos imaturos: metamorfose e identificação. Ribeirão Preto, Holos Editora, 249p.

Costa, W.J.E.M. 1987. Feeding habits of a fish community in a tropical coastal stream, Rio Mato Grosso, Brazil. Studies on Neotropical Fauna \& Environment 22 (3): 145-153.

Costello, M.J. 1990. Predator feeding strategy and prey importance: a new graphical analysis. Journal of Fish Biology 36 (2): 261-263.

Delariva, R.L.; A.A. Agostinho; K. NaKatani \& G. Baumgartner. 1994. Ichthyofauna associated to aquatic macrophytes in the Upper Paraná river floodplain. Revista Unimar 16: 41-60.

Esteves, K.E. 1996. Feeding ecology of three Astyanax species (Characidae, Tetragonopterinae) from a floodplain lake of Mogi-Guaçú River, Paraná River Basin, Brazil. Environmental Biology of Fishes 46 (1): 83-101.

Esteves, K.E. \& P.M. Galetti JR. 1995. Food partitioning among some characids of a small Brazilian floodplain lake from the Paraná River basin. Environmental Biology of Fishes 42 (4): 375-389.

Ferreira, A.; N.S. Hahn \& R.L. Delariva. 2002. Ecologia alimentar de Piabina argentea (Teleostei, Tetragonopterinae) nas fases de pré e pós-represamento do rio Corumbá, GO. Acta Limnologica Brasiliensia 14 (1): 43-52.

Gelwick, F.P. \& W.J. MatThews. 1996. Trophic relations of stream fishes, p. 475-492. In: G. LAMBERTI \& R. HAUER (Eds). Methods in stream ecology. New York, New York Academic Press, 673p.

Goldstein, R.M. \& T.P. Simon. 1999. Toward a united definition of guild structure for feeding ecology of North American freshwater fishes, p. 123-138. In: T.P. SIMON (Ed.). Assessing the sustainability and biological integrity of water resources using fish communities. Boca Raton, CRC Press, $672 \mathrm{p}$.

Grant, J.W.A. \& D.L.G. Noakes. 1987. A simple model of optimal territory size for drift-feeding fishes. Canadian Journal of Zoology 65 (2): 270-276.

Gregory, K.J. 1992. Vegetation and river channel process interactions, p. 255-269. In: P.J. Boon; P. Calow \& G.E. PetTs (Eds). River Conservation and Management. Chichester, John Wiley \& Sons, 470p.
Hynes, H.B.N. 1950. The food of fresh-water sticklebacks (Gasterosteus aculeatus and Pygosteus pungitius), with a review of methods used in studies of the food of fishes. Journal of Animal Ecology 19: 36-58.

IPT. 2000. Diagnóstico da situação atual dos Recursos Hídricos e estabelecimento de diretrizes técnicas para a elaboração do plano da Bacia Hidrográfica do São José dos Dourados. São Paulo, Instituto de Pesquisas Tecnológicas do estado de São Paulo, Fundo Estadual de Recursos Hídricos, Relatório n ${ }^{\circ} 40675,119$ p.

KiKuCHI, R.M. \& V.S. Uieda. 1998. Composição da comunidade de invertebrados de um ambiente lótico tropical e sua variação espacial e temporal, p. 157-173. In: J.L. Nessimian \& E. Carvalho (Eds). Ecologia de insetos aquáticos. Rio de Janeiro, PPGE-UFRJ, Série Oecologia Brasiliensis, 309p.

Loвв, M.D. \& D.J. OrTh. 1991. Habitat use by an assemblage of fish in a large warm water stream. Transactions of the American Fisheries Society 120 (1): 65-78.

Lowe-McConNelL, R.H. 1987. Ecological studies in tropical fish communities. Cambridge, Cambridge University Press, 382p.

Melo, C.H.; F.A. Machado \& V. Pinto-Silva. 2004. Feeding habits of fish from a stream in the savanna of Central Brazil, Araguaia Basin. Neotropical Ichthyology 2 (1): 37-44.

Mitchell, S.C. 2005. How useful is the habitat concept? - a critique. Oikos 110 (3): 634-368.

Morris, R.J.; O.T. Lewis \& H.C.J. Godfray. 2004. Experimental evidence for apparent competition in a tropical forest food web. Nature 428: 310-313.

Nimer, E. 1989. Climatologia do Brasil. Rio de Janeiro, IBGE, $421 \mathrm{p}$.

Pianka, E.R. 2000. Evolutionary ecology. San Francisco, Addison Wesley Educational Publishers, 356p.

Poulet, N.; L. Lek \& C. Argillier. 2005. Pike perch habitat use within a canal network in spring. Journal of Fish Biology 67 (5): 1460-1474.

Pusey, B.J. \& A.H. Arthington. 2003. Importance of the riparian zone to the conservation and management of freshwater fish: a review. Marine and Freshwater Research 54 (1): 1-16.

Rezende, C.F. \& R. Mazzoni. 2003. Aspectos da alimentação de Bryconamericus microcephalus (Characiformes, Tetragonopterinae) no córrego Andorinha, Ilha Grande, RJ. Biota Neotropica 3 (1): 1-6.

Rincón, P.A. 1999. Uso do micro-hábitat em peixes de riachos: métodos e perspectivas, p. 23-90. In: E.P. CARAMASCHI; R. MAZzONI $\&$ P.R. Peres-Neto (Eds). Ecologia de peixes de riachos. Rio de Janeiro, PPGE-UFRJ, Série Oecologia Brasiliensis, 276p.

RoHLF, F.J. 2000. NTSYS 2.1: numerical taxonomic and multivariate analysis system. New York, Exeter Software, 38p.

Sabino, J. \& R.M.C. Castro. 1990. Alimentação, período de atividade e distribuição espacial dos peixes de um riacho da Floresta Atlântica (Sudeste do Brasil). Revista Brasileira de Biologia 50 (1): 23-36. 
Sabino, J. \& J. Zunanon. 1998. A stream fish assemblage in Central Amazonian: distribution, activity patterns, and feeding behavior. Ichthyological Explorations of Freshwaters 8: 201-210.

SAZIMA, I. 1986. Similarities in feeding behaviour between some marine and freshwater fishes in two tropical communities. Journal of Fish Biology 29 (1): 53-65.

Schoener, T.W. 1974. Resource partitioning in ecological communities. Science 185 (4145): 27-39.

SILVA, C.S. 1992. Distribuição e abundância da fauna macrobentônica do complexo estuarino Mundaú/Manguaba (Alagoas, Brasil). Boletim dos Estudos de Ciências do Mar 6: 45-64.

SweEney, B.W.; T.L. BotT; J.K. Jackson; L.A. Kaplan; J.D. Newbold; L.J. Standley; W.C. Hession \& R.J. Horwitz. 2004. Riparian deforestation, stream narrowing, and loss of stream ecosystem services. Proceedings of the National Academy of Sciences 101 (39): 14132-14137.
Ter Braak, C.J.F. \& P. Smilauer. 2002. CANOCO Reference manual and CanoDraw for Windows user's guide: Software for Canonical Community Ordination (version 4.5). Ithaca, Microcomputer Power, 500p.

UiedA, V.S. \& M.G. BARRETo. 1999. Composição da ictiofauna de quatro trechos de diferentes ordens do Rio Capivara, bacia do Tietê, Botucatu, São Paulo. Revista Brasileira de Zoociências 1 (1): 55-67.

UiedA, V.S.; P. Buzzato \& R.M. KIKUCHI. 1997. Partilha de recursos alimentares em peixes de um riacho de serra no sudeste do Brasil. Anais da Academia Brasileira de Ciências 69 (1): 243-252.

Waite, I.R. \& K.D. Carpenter. 2000. Associations among fish assemblage structure and environmental variables in Willamette basin streams, Oregon. Transactions of the American Fisheries Society 129 (3): 754-770.

WIENS, J.A. 1977. On competition and variable environments. American Scientist 65 (5): 590-597.

Appendix 1. Coordinates of streams sampled (S1-S22) for mesohabitat analysis.

\begin{tabular}{|c|c|c|c|c|c|}
\hline Streams & Latitude & Longitude & Streams & Latitude & Longitude \\
\hline $\mathrm{S} 1^{*}$ & $20^{\circ} 26^{\prime} 39.2^{\prime \prime} \mathrm{S}$ & $50^{\circ} 15^{\prime} 47.8^{\prime \prime} \mathrm{W}$ & $\mathrm{S} 12$ & $19^{\circ} 58^{\prime} 21.9^{\prime \prime S}$ & $50^{\circ} 26^{\prime} 50.2^{\prime \prime} \mathrm{W}$ \\
\hline $\mathrm{S} 2^{*}$ & $20^{\circ} 36^{\prime} 20.7^{\prime \prime S}$ & $50^{\circ} 34^{\prime} 05.0^{\prime \prime} \mathrm{W}$ & S13* & $20^{\circ} 14^{\prime} 37.0^{\prime \prime} \mathrm{S}$ & $50^{\circ} 29^{\prime} 05.5^{\prime \prime} \mathrm{W}$ \\
\hline S3* & $20^{\circ} 35^{\prime} 49.5^{\prime \prime} \mathrm{S}$ & $50^{\circ} 45^{\prime} 29.2^{\prime \prime} \mathrm{W}$ & S14* & $20^{\circ} 09^{\prime} 18.0^{\prime \prime S}$ & $50^{\circ} 26^{\prime} 15.2^{\prime \prime} \mathrm{W}$ \\
\hline S4 & $20^{\circ} 31^{\prime} 28.8^{\prime \prime S}$ & $51^{\circ} 02^{\prime} 56.4^{\prime \prime} \mathrm{W}$ & $\mathrm{S} 15^{*}$ & $20^{\circ} 10^{\prime} 06.5^{\prime \prime S}$ & $50^{\circ} 29^{\prime} 34.2^{\prime \prime} \mathrm{W}$ \\
\hline S5* & $20^{\circ} 22^{\prime} 58.6^{\prime \prime} \mathrm{S}$ & $50^{\circ} 35^{\prime} 08.6^{\prime \prime} \mathrm{W}$ & S16 & $20^{\circ} 07^{\prime} 43.7^{\prime \prime S}$ & $50^{\circ} 29^{\prime} 28.9^{\prime \prime} \mathrm{W}$ \\
\hline$S 6^{*}$ & $20^{\circ} 20^{\prime} 51.3^{\prime \prime} \mathrm{S}$ & $50^{\circ} 40^{\prime} 42.6^{\prime \prime} \mathrm{W}$ & S17* & $20^{\circ} 08^{\prime} 32.8^{\prime \prime} \mathrm{S}$ & $50^{\circ} 22^{\prime} 47.5^{\prime \prime} \mathrm{W}$ \\
\hline S7* & $20^{\circ} 23^{\prime} 11.3^{\prime \prime S}$ & $50^{\circ} 46^{\prime} 54.3^{\prime \prime} \mathrm{W}$ & S18 & $20^{\circ} 11^{\prime} 48.4^{\prime \prime S}$ & $50^{\circ} 38^{\prime} 18.9^{\prime \prime} \mathrm{W}$ \\
\hline S8 & $20^{\circ} 25^{\prime} 53.7^{\prime \prime} \mathrm{S}$ & $50^{\circ} 48^{\prime} 53.7^{\prime \prime} \mathrm{W}$ & S19* & $20^{\circ} 03^{\prime} 25.0^{\prime \prime} \mathrm{S}$ & $50^{\circ} 41^{\prime} 20.1^{\prime \prime} \mathrm{W}$ \\
\hline S9* & $20^{\circ} 31^{\prime} 08.1^{\prime \prime S}$ & $50^{\circ} 55^{\prime} 37.1^{\prime \prime} \mathrm{W}$ & S20* & $20^{\circ} 08^{\prime} 34.9^{\prime \prime} \mathrm{S}$ & $50^{\circ} 46^{\prime} 33.3^{\prime \prime} \mathrm{W}$ \\
\hline S10* & $20^{\circ} 09^{\prime} 15.9^{\prime \prime S}$ & $50^{\circ} 54^{\prime} 46.5^{\prime \prime} \mathrm{W}$ & S21 & $20^{\circ} 08^{\prime} 00.2^{\prime \prime} \mathrm{S}$ & $50^{\circ} 48^{\prime} 56.8^{\prime \prime} \mathrm{W}$ \\
\hline S11 & $20^{\circ} 00^{\prime} 49.7^{\prime \prime S}$ & $50^{\circ} 02^{\prime} 24.0^{\prime \prime} \mathrm{W}$ & $S 22^{*}$ & $20^{\circ} 04^{\prime} 45.5^{\prime \prime} \mathrm{S}$ & $50^{\circ} 56^{\prime} 28.3^{\prime \prime} \mathrm{W}$ \\
\hline
\end{tabular}

* The 15 streams in which feeding analysis was also carried out.

Submitted: 30.1.2009; Accepted: 26.1.2010.

Editorial responsibility: Rosana Mazzoni 